Original Research

\title{
Comparison of Heavy Metal Levels in Muscle and Gills of Four Benthic Fish Species from the Northeastern Mediterranean Sea
}

\author{
Mine Perçin Olgunoğlu*, Engin Artar, İlkan Ali Olgunoğlu \\ Department of Aquaculture and Fisheries Program, Kahta Vocational Training School, \\ Adiyaman University, Turkey \\ Received: 7 January 2015 \\ Accepted: 5 March 2015
}

\begin{abstract}
In the present study, the concentration of cadmium $(\mathrm{Cd})$, lead $(\mathrm{Pb})$, copper $(\mathrm{Cu})$, zinc $(\mathrm{Zn})$, and iron $(\mathrm{Fe})$ in the gill and muscle tissues of four benthic fish species (Merluccius merluccius, Lophius budegassa, Helicolenus dactylopterus, and Chlorophthalmus agassizi) from the northeastern Mediterranean Sea in Turkey were investigated. From the obtained results, the heavy metal concentrations in muscle were lowest and highest in the gills for each species. $\mathrm{Cd}$ was not detected in any tissues of the species. The order of heavy metal concentrations were found as $\mathrm{Zn}>\mathrm{Fe}>\mathrm{Cu}>\mathrm{Pb}=\mathrm{Cd}$ in muscle tissue samples for four selected fish species $(\mathrm{p}<0.05)$. In the muscle tissue, the highest concentration of $\mathrm{Zn}(5.875 \mu \mathrm{g} / \mathrm{g})$ was found in Lophius budegassa. The concentrations of heavy metals in gills of four selected fish species were $\mathrm{Fe}>\mathrm{Zn}>\mathrm{Cu}>\mathrm{Pb}>\mathrm{Cd}(\mathrm{p}<0.05)$. In the gills, the highest concentration of $\mathrm{Fe}(73.730 \mu \mathrm{g} / \mathrm{g})$ was also found in Lophius budegassa. The comparison of our results with previous studies showed that the metal levels of tissues are variable in organisms caught from the same area. In our study, the concentrations of $\mathrm{Cd}, \mathrm{Pb}, \mathrm{Cu}, \mathrm{Zn}$, and $\mathrm{Fe}$ in the muscle tissue are less than the permissible limits set for heavy metals by food regulations.
\end{abstract}

Keywords: heavy metals, fish, northeastern Mediterranean Sea, gill, muscle

\section{Introduction}

Heavy metals are of particular concern due to their toxicity and bioaccumulation ability in aquatic ecosystems and aquatic organisms. In general, they are not biodegradable and have long biological halflives. According to the World Health Organization (WHO), heavy metals must be controlled in food sources in order to assure public safety [1]. Heavy metals are taken up and accumulated by aquatic organisms both from the surrounding medium and via food sources (deep-sea carnivorous fish in particular accumulate metals in their muscles via the food chain). The extent of heavy metal accumula-

*e-mail: mineper@yahoo.com tion is affected by external (dissolved metals, physicochemistry, dissolved oxygen, interactions between metals, sediment, food, seasonal effects, geographical differences) and internal (individual variability, body size and development stage, sex, breeding condition, brooding, moulting and growth, behaviour) factors [2,3].

Many species of marine benthic fish are largely being used to assess the quality of aquatic environments because they could concentrate large amounts of some metals in different tissues such as muscle and gills [4, 5]. The gills are considered the main site of entry for the dissolved metals. They are sensitive to any change of water components and serve as a good indicator of water quality since gill filaments and lamellae provide a very large surface area for direct and continuous contact with contaminants 
in water. Therefore, the concentration of metals in gills reflects their concentration in water where the fish live [68].

In the present study we selected gills as a primary site of metal uptake and muscle as specialized in metal storage. The main objective of this study was to present the level of five metals, namely cadmium $(\mathrm{Cd})$, lead $(\mathrm{Pb})$, copper $(\mathrm{Cu})$, zinc $(\mathrm{Zn})$, and iron $(\mathrm{Fe})$ in gills and muscle tissue of four commercially valuable benthic marine fish species (Merluccius merluccius, Lophius budegassa, Helicolenus dactylopterus, and Chlorophthalmus agassizi) contributing to the effective monitoring of both environmental quality and the health of the organisms caught from the northeastern Mediterranean.

\section{Materials and Methods}

\section{Collection and Preparation of Samples}

The fish samples were caught by bottom trawlers between 459 and $582 \mathrm{~m}$ deep, in the Turkey's northeastern Mediterranean Sea $\left(36^{\circ} 08^{\prime} 604^{\prime \prime} \mathrm{N}-34^{\circ} 38^{\prime} 593^{\prime \prime E} / 36^{\circ} 17^{\prime} 766^{\prime \prime}\right.$ N-34 22'533"E) (Fig. 1).

Immediately after collection, samples were washed with clean sea water at the point of collection, separated by species, stored in a container, preserved in crushed ice, and transferred to the laboratory where the total size and weight of the samples were measured and the gut content, edible tissue, and gills were separated. Then samples were placed in labeled polyethylene bags and stored at $-20^{\circ} \mathrm{C}$ until processing for metal analysis. Sixteen samples from each fish species were obtained from the sampling area.

\section{Determination of Heavy Metals}

The edible tissue and gill samples were transported with dry ice to the Accredited Industrial Services Laboratory of
Turkey/Izmir. For each fish species, $2 \mathrm{~g}$ of edible tissue and gill (wet weight) were weighed and placed in a digestion vessel with $5 \mathrm{ml}$ of concentrated $(65 \%)$ nitric acid $\left(\mathrm{HNO}_{3}\right)$ and $2 \mathrm{ml}(30 \%)$ hydrogen peroxide $\left(\mathrm{H}_{2} \mathrm{O}_{2}\right)$, and digested in a microwave oven system [9]. Inductively Coupled Plasma - Optical Emission Spectrometry (ICP-OES-Perkin Elmer Optima $8000^{\circ}$ ) was used for determination of $\mathrm{Cd}, \mathrm{Pb}, \mathrm{Cu}$, $\mathrm{Zn}$, and $\mathrm{Fe}$ in the samples. The concentrations were expressed as $\mu \mathrm{g} / \mathrm{g}$ wet weight.

\section{Data Analysis}

For data analysis, analysis of variance and Duncan's multiple range test were employed using SPSS 15.0 Windows Software for finding out statistical differences among various parameters. Statistical significance was defined at $\mathrm{p}<0.05$. The mean values were obtained from 3 experiments and reported as means $\pm \mathrm{SD}$.

\section{Results and Discussion}

The amount of bioaccumulations of heavy metals in tissues may vary depending on length and weight of samples [10]. Table 1 shows mean length $(\mathrm{cm})$ and weights $(\mathrm{g})$ of the species examined in the study.

The mean and comparison of heavy metal levels $(\mu \mathrm{g} / \mathrm{g})$ in tissues for the selected four fish species (Merluccius merluccius, Lophius budegassa, Helicolenus dactylopterus, and Chlorophthalmus agassizi) are presented in Table 2. As shown in Table 2, this investigation showed that the mean concentration of heavy metals in tissues was quite different (varied significantly) among the four species $(p<0.05)$. Recent studies have indicated that different fish species from the same area contained different metal levels in their tissues. Heavy metal bioaccumulation of fish is speciesdependent. Feeding habits and lifestyles of species are strongly related to accumulation levels [11-13].

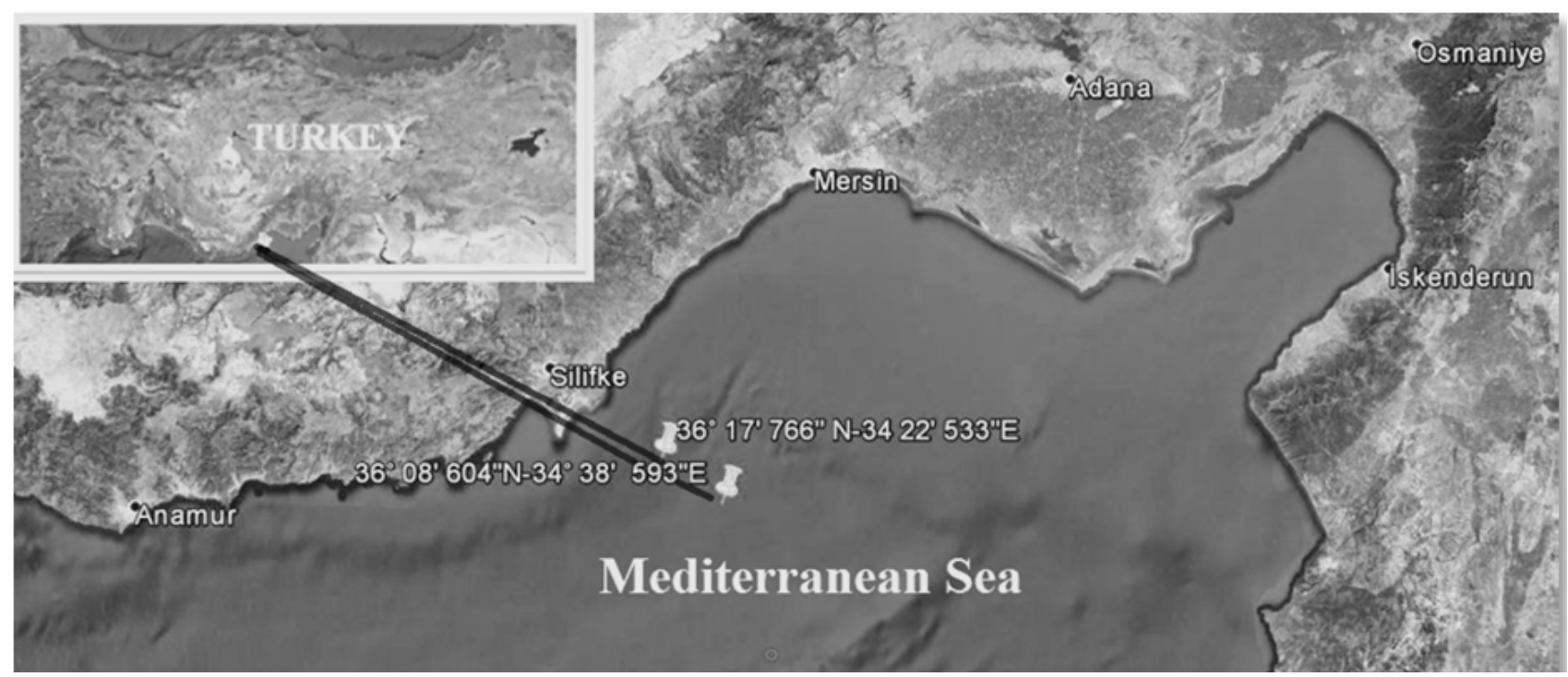

Fig. 1. Sampling area in the northeastern Mediterranean Sea. 
Table 1. Mean weights and lengths of the species examined in the study (mean $\pm \mathrm{SD})$.

\begin{tabular}{|c|c|c|c|c|c|}
\hline Parameter & $\mathrm{n}$ & M. merluccius & L. budegassa & H. dactylopterus & C. agassizi \\
\hline Weight $(\mathrm{g})$ & 16 & $60.26 \pm 50.53$ & $217.83 \pm 28.45$ & $80.05 \pm 21.66$ & $30.03 \pm 7.87$ \\
\hline Lenght $(\mathrm{cm})$ & 16 & $19.01 \pm 3.99$ & $23.75 \pm 1.06$ & $17.55 \pm 1.08$ & $15.55 \pm 1.62$ \\
\hline
\end{tabular}

Table 2. Concentrations of heavy metals in muscle tissue and gill of selected benthic fish species $(\mu \mathrm{g} / \mathrm{g})$.

\begin{tabular}{|c|c|c|c|c|}
\hline \multirow{2}{*}{ Heavy Metals } & \multicolumn{4}{|c|}{ Muscle } \\
\hline & M. merluccius & L. budegassa & H. dactylopterus & C. agassizi \\
\hline $\mathrm{Cd}$ & n.d & n.d & n.d & n.d \\
\hline $\mathrm{Pb}$ & n.d & n.d & n.d & n.d \\
\hline $\mathrm{Cu}$ & $0.258^{\mathrm{c}} \pm 0.002$ & $0.186^{\mathrm{a}} \pm 0.001$ & $0.222^{\mathrm{b}} \pm 0.001$ & $0.288^{\mathrm{d}} \pm 0.002$ \\
\hline $\mathrm{Zn}$ & $3.692^{\mathrm{a}} \pm 0.003$ & $5.875^{\mathrm{d}} \pm 0.004$ & $4.500^{b} \pm 0.001$ & $5.370^{\mathrm{c}} \pm 0.003$ \\
\hline $\mathrm{Fe}$ & $2.584^{\mathrm{a}} \pm 0.004$ & $2.469^{\mathrm{d}} \pm 0.003$ & $3.283^{b} \pm 0.003$ & $2.934^{\mathrm{c}} \pm 0.004$ \\
\hline \multirow{2}{*}{ Heavy Metals } & \multicolumn{4}{|c|}{ Gill } \\
\hline & M. merluccius & L. budegassa & H. dactylopterus & C. agassizi \\
\hline $\mathrm{Cd}$ & n.d & n.d & n.d & n.d \\
\hline $\mathrm{Pb}$ & n.d & n.d & n.d & $0.133 \pm 0.003$ \\
\hline $\mathrm{Cu}$ & $1.037^{\mathrm{c}} \pm 0.001$ & $0.957^{b} \pm 0.002$ & $0.653^{a} \pm 0.006$ & $1.086^{\mathrm{d}} \pm 0.004$ \\
\hline $\mathrm{Zn}$ & $29.400^{b} \pm 1.00$ & $14.470^{\mathrm{a}} \pm 0.08$ & $32.960^{\mathrm{c}} \pm 0.09$ & $33.840^{\mathrm{c}} \pm 0.04$ \\
\hline $\mathrm{Fe}$ & $55.200^{c} \pm 0.09$ & $73.730^{\mathrm{d}} \pm 1.07$ & $42.940^{b} \pm 1.01$ & $42.560^{\mathrm{a}} \pm 0.06$ \\
\hline
\end{tabular}

n.d. - below detection limit; limits of detection of measurements are $0.1 \mathrm{ppb}$ for $\mathrm{Cd}$ and $1 \mathrm{ppb}$ for $\mathrm{Pb}$; data are expressed as mean $\pm \mathrm{SD}$ of triplicate measurements. Different superscripts within the same row show significant differences between samples $(p<0.05)$.

In the study, there were great variations among amounts of $\mathrm{Zn}, \mathrm{Cu}$, and $\mathrm{Fe}$ accumulation in investigated tissues of the species $(\mathrm{p}<0.05)$. Metal ions are first absorbed through the gills because they are directly in contact with the contaminated medium and also have the thinnest epithelium when compared to other organs [14]. Besides, it was reported that active metabolite organs such as gill accumulate more heavy metals than other tissues, like muscle $[12,13]$. Therefore, in our study the highest concentrations of metals were found in gill, while the lowest concentrations were in the muscle tissue for all species. Canli and Atli [15] pointed out that heavy metal concentrations in gill of Mediterranean fish species are higher than the muscle tissues. Our results are also in agreement with the many authors who have reported that gills have a high tendency to accumulate heavy metals [16-18]. On the other hand, the accumulation orders of heavy metals in the tissues (gill and muscle) were nearly similar. The mean concentration of measured metals in gills was found to be in the following order: $\mathrm{Fe}>\mathrm{Zn}>\mathrm{Cu}>\mathrm{Pb}>\mathrm{Cd}$. $\mathrm{Cu}$ and $\mathrm{Fe}$ concentrations were significantly different in the gills of all fish samples. Significant differences of $\mathrm{Zn}$ concentrations were found in gills only between $M$. merluccius and L. budegassa. Distribution patterns of metal concentrations in the muscle of the fish species follow the sequence: $\mathrm{Zn}>\mathrm{Fe}>\mathrm{Cu}>\mathrm{Pb}=\mathrm{Cd}$. Significant differences of heavy metal concentrations were found in the muscle between all species $(\mathrm{p}<0.05)$.
In the gills, the highest metal concentration was found as Fe $(73.730 \mu \mathrm{g} / \mathrm{g})$ in Lophius budegassa, the lowest was found in C. agassizi as $42.56 \mu \mathrm{g} / \mathrm{g}$. Similarly, Akan et al. [19] reported the highest concentration of Fe in gill of Synodentis budgetti. Zn concentration was the second highest in the metals among the species, in which C. agassizi had the highest concentration $(33.84 \mu \mathrm{g} / \mathrm{g})$ and L. budegas$s a$ had the lowest $(14.47 \mu \mathrm{g} / \mathrm{g})$. The observed concentration of $\mathrm{Cu}$ in gills was higher in C. agassizi $(1.086 \mu \mathrm{g} / \mathrm{g})$. Pb was detected only in gill of $C$. agassizi as $0.133 \mu \mathrm{g} / \mathrm{g}$ ( $\mathrm{Pb}$ was below the detection limit of the ICP-OES in other all tissues of species). Cd was not detected in any tissues of the species examined in the study. This may arise from the fact that $\mathrm{Cd}$ and $\mathrm{Pb}$ are either only in trace amounts in their habitats or these elements are not biomagnified in fish tissues [12].

In the muscle tissue, $\mathrm{Zn}$ showed the highest level (5.875 $\mu \mathrm{g} / \mathrm{g}$ ) in L. budegassa while the lowest level was in Merluccius merluccius (3.692 $\mu \mathrm{g} / \mathrm{g})$. Zn, being an essential element for normal growth and metabolism of organisms, exhibited the highest accumulation in the organism when compared with other metals [20]. According to Pourang et al. [21], $\mathrm{Zn}$ is the most abundant element in the muscle followed by other metals. Krishna et al. [22] reported that the highest concentration of the metal in edible organs of fishes was $\mathrm{Zn}$. Our results are in agreement with the results reported on $\mathrm{Zn}$. The maximum and minimum concentra- 
Table 3. Heavy metals concentrations $(\mu \mathrm{g} / \mathrm{g})$ in some fish species collected from the Northeast Mediterranean Sea.

\begin{tabular}{|c|c|c|c|c|}
\hline Species & Metals & Muscle & Gill & Reference \\
\hline Mugil cephalus & \multirow{7}{*}{$\mathrm{Cd}$} & $0.86-1.46$ & $2.19-3.65$ & [3] \\
\hline Mullus barbatus & & $1.03-2.27$ & $2.25-6.20$ & {$[3-27]$} \\
\hline Caranx crysos & & $0.61-1.36$ & $2.64-3.34$ & [27] \\
\hline Sparus aurata & & $1.40-1.78$ & & [28] \\
\hline Saurida undosquamis & & $0.51-2.48$ & & [28] \\
\hline Dicentrarchus labrax & & 0.06 & 0.92 & [11] \\
\hline Lophius budegassa & & 0.02 & & [24] \\
\hline Merluccius merluccius & \multirow{11}{*}{$\mathrm{Pb}$} & 6.00 & & [23] \\
\hline Solea solea & & 6.56 & & {$[23]$} \\
\hline Mullus barbatus & & $6.34-6.82$ & 24.52 & {$[3-23]$} \\
\hline Lithognathus mormyrus & & 5.60 & & {$[23]$} \\
\hline Mugil cephalus & & $5.44-7.33$ & $20.17-21.17$ & {$[3-27]$} \\
\hline Caranx crysos & & $4.43-7.50$ & $17.51-20.11$ & [27] \\
\hline Spaurus aurata & & $4.84-7.33$ & & {$[10]$} \\
\hline Trachurus mediterraneus & & $0.71-1.38$ & & {$[24]$} \\
\hline Saurida undosquamis & & $2.99-4.14$ & & [28] \\
\hline Dicentrarchus labrax & & 0.82 & 4.42 & [11] \\
\hline Lophius budegassa & & 0.17 & & [24] \\
\hline Solea solea & \multirow{10}{*}{$\mathrm{Cu}$} & 6.68 & & [23] \\
\hline Merluccius merluccius & & 0.38 & & [23] \\
\hline Mullus barbatus & & $1.17-12.95$ & 15.32 & {$[3-23]$} \\
\hline Lithognathus mormyrus & & 1.09 & & [23] \\
\hline Mugil cephalus & & $3.92-9.82$ & $6.18-12.17$ & {$[3-27]$} \\
\hline Caranx crysos & & $2.74-6.15$ & $9.14-16.99$ & {$[27]$} \\
\hline Spaurus aurata & & $0.32-0.51$ & & {$[10]$} \\
\hline Trachurus mediterraneus & & $0.66-1.91$ & & {$[24]$} \\
\hline Saurida undosquamis & & $0.63-2.21$ & & [28] \\
\hline Dicentrarchus labrax & & 0.33 & 1.79 & [11] \\
\hline Merluccius merluccius & \multirow{10}{*}{$\mathrm{Zn}$} & 19.82 & & {$[23]$} \\
\hline Solea solea & & 22.84 & & {$[23]$} \\
\hline Mullus barbatus & & $25.12-29.15$ & 68.20 & {$[3-23]$} \\
\hline Lithognathus mormyrus & & 26.91 & & [23] \\
\hline Mugil cephalus & & $23.5-30.90$ & 2 & {$[3-27]$} \\
\hline Caranx crysos & & $18.00-33.60$ & $40.30-67.70$ & [27] \\
\hline Spaurus aurata & & $19.31-31.23$ & & {$[10]$} \\
\hline Trachurus mediterraneus & & $8.99-30.42$ & & {$[24]$} \\
\hline Saurida undosquamis & & $1.85-4.63$ & & [28] \\
\hline Dicentrarchus labrax & & 52.22 & 47.66 & {$[11]$} \\
\hline
\end{tabular}


Table 3. Continued.

\begin{tabular}{|c|c|c|c|c|}
\hline Species & Metals & Muscle & Gill & Reference \\
\hline Merluccius merluccius & \multirow{10}{*}{$\mathrm{Fe}$} & 83.97 & & {$[23]$} \\
\hline Solea solea & & 91.91 & & {$[23]$} \\
\hline Mullus barbatus & & $45.17-69.85$ & 161.05 & {$[3-23]$} \\
\hline Lithognathus mormyrus & & 89.94 & & {$[23]$} \\
\hline Mugil cephalus & & $33.12-129.00$ & $139.50-238.00$ & {$[3-27]$} \\
\hline Caranx crysos & & $36.4-66.80$ & $173.00-270$ & {$[27]$} \\
\hline Sparus aurata & & $20.65-28.81$ & & {$[10]$} \\
\hline Trachurus mediterraneus & & $29.10-57.52$ & & {$[25]$} \\
\hline Saurida undosquamis & & $2.38-7.3$ & & {$[28]$} \\
\hline Dicentrarchus labrax & & 9.84 & 190.76 & [11] \\
\hline
\end{tabular}

Table 4. Maximum permissible limits of heavy metals in fish muscles ( $\mu \mathrm{g} / \mathrm{g}$ wet wt.) according to international standards [29].

\begin{tabular}{|c|c|c|c|c|c|}
\hline & \multicolumn{5}{|c|}{ Metals } \\
\hline & $\mathrm{Cd}$ & $\mathrm{Pb}$ & $\mathrm{Cu}$ & $\mathrm{Zn}$ & $\mathrm{Fe}$ \\
\hline FAO (1983) & 0.05 & 0.5 & 30 & 30 & \\
\hline FAO/WHO limit & 0.5 & 0.5 & 30 & 40 & \\
\hline WHO 1989 & 1 & 2 & 30 & 100 & 100 \\
\hline European community & 0.05 & 0.2 & & & \\
\hline Turkish guidlines & 0.05 & 0.3 & & & \\
\hline
\end{tabular}

tions of Fe were obtained in H. dactylopterus and L. budegassa as $3.283 \mu \mathrm{g} / \mathrm{g}$ and $2.469 \mu \mathrm{g} / \mathrm{g}$, respectively. The highest level of $\mathrm{Cu}$ was found in C. agassizi $(0.288 \mu \mathrm{g} / \mathrm{g})$, the lowest value was detected in L. budegassa $(0.186 \mu \mathrm{g} / \mathrm{g})$.

A comparison of mean concentrations of metals in tissues of some species from the northeastern Mediterranean Sea is given in Table 3, which demonstrates that the metal levels of tissues are variable in organisms and reflect the level of contamination in the sampling areas. As seen in Table 3, the $\mathrm{Cd}, \mathrm{Pb}, \mathrm{Cu}, \mathrm{Zn}$, and Fe concentrations in tissue of some marine fishes seem to be higher than the present study. For example, Külcü et al. [23] reported that the $\mathrm{Pb}$, $\mathrm{Cu}, \mathrm{Zn}$, and $\mathrm{Fe}$ levels in muscle tissues of M. merluccius were higher than those found in our study for same species. Similarly, Renieri et al. [24] pointed out that the $\mathrm{Cd}$ and $\mathrm{Pb}$ contents in muscle tissue of L. budegassa were also higher than those found in our study for same species. This is perhaps due to our sampling area being a less contaminated marine environment compared to water (sampling area) given in Table 3. However, all the previous studies indicated that various factors such as season, length and weight, different ecological needs, metabolism and feeding patterns of fish, physical and chemical status of water type, and the level of water pollution can play a role in the tissue accumulation of metals $[11,25,26]$.
The levels of $\mathrm{Cd}, \mathrm{Pb}, \mathrm{Cu}, \mathrm{Zn}$, and $\mathrm{Fe}$ determined in the muscles of the four studied fish species were lower than the permisseble values described in the literature (Table 4). Consequently, it can be concluded that the metal concentrations were below international admissible limits for human consumption for all of the studied samples in this region.

\section{Conclusions}

Based on the result of this study, the levels of heavy metal concentrations in tissues (gill and muscle) of Merluccius merluccius, Lophius budegassa, Helicolenus dactylopterus, and Chlorophthalmus agassizi caught from the northeastern Mediterranean Sea did not exceed the permissible limits set for the studied heavy metals by regulations. Therefore, these fish in this area of study did not pose any threat to humans upon consumption. But it may be suggested that continuous care must be taken (especially seasonal) to biomonitor the heavy metal levels if they exceed the maximum permitted concentrations for human consumption. The highest levels of all the metals in the present study were observed in gills of the four fish samples, while muscle showed the lowest value. However, the results in this study demonstrate that the 
metal levels of tissues are quite variable and lower than the results in fish tissues previously reported from the northeastern Mediterranean.

\section{References}

1. HEIDARIEH M., MARAGHEH., M.G., SHAMAMI M.A., BEHGAR M., ZIAEI F., AKBARI Z. Evaluate of heavy metal concentration in shrimp (Penaeus semisulcatus) and crab (Portunus pelagicus) with INAA method. SpringerPlus 2, 72, 2013.

2. GOKOGLU N., YERLIKAYA P., GOKOGLU M. Trace elements in edible tissues of three shrimp species (Penaeus semisulcatus, Parapenaeus longirostris and Paleomon serratus). J Sci. Food Agric. 88, 175, 2008.

3. ÇOĞUN H.Y., YÜZEREROĞLU T.A., FIRAT Ö., GÖK G., KARGIN F. Metal concentrations in fish species from the northeast mediterranean sea. Environ. Monit. Assess. 121, 431, 2006.

4. FAROMBI E.O., ADELOWO O.A., AJIMOKO Y.R. Biomarkers of oxidative stress and heavy metal levels as indicators of environmental pollution in African Cat Fish (Clarias gariepinus) from Nigeria Ogun River. Int. J. Environ. Res. Public Health. 4, (2), 158, 2007.

5. SAFAHIEH A., MONIKH F.A., RONAGH M.T., SAVARI A., DORAGHI A. Determination of heavy metals (Cd, Co, $\mathrm{Cu}, \mathrm{Ni}$ and $\mathrm{Pb}$ ) in croacker fish (Johnius belangerii) from Musa estuary in the Persian Gulf. Int. J. Environ. Sci. Dev. 2, (6), 460, 2011.

6. GABER H.S. Impact of certain heavy metals on the gill and liver of the Nile Tilapia (Oreochromis Niloticus). Egypt. J. Aquat. Biol. Fish. 11, (2), 100, 2007.

7. CHAVAN V.R., MULEY D.V. Effect of heavy metals on liver and gill of fish Cirrhinus mrigala. Int. J. Curr. Microbiol. App. Sci. 3, (5), 277, 2014.

8. RAUF A., JAVED M., UBAIDULLAH M. Heavy metal levels in three major carps (Catla catla, Labeo rohita and Cirrhina mrigala) from the river Ravi, Pakistan. Pakistan Vet. J., 29, (1), 24, 2009.

9. Nordic Committee on Food Analysis (NMKL) method No 161. Metals, determination by atomic absorbtion spectrophotometry after wet digestion in microwave oven. pp. 8, 1998.

10. YILMAZ A.B. Comparison of heavy metal levels of grey mullet (Mugil cephalus L.) and sea bream (Sparus aurata L.) caught in Iskenderun Bay (Turkey). Turk. J. Vet. Anim. Sci. 29, 257, 2005.

11. DURAL M., GÖKSU M.Z.L., ÖZAK A.K. Investigation of heavy metal levels in economically important fish species captured from the Tuzla lagoon. Food Chem. 102, 415, 2007.

12. UYSAL K., EMRE Y., KÖSE E. The determination of heavy metal accumulation ratios in muscle, skin and gills of some migratory fish species by inductively coupled plasmaoptical emissionspectrometry (ICP-OES) in Beymelek Lagoon (Antalya/Turkey). Microchem. J. 90, 67, 2008.

13. KHEZRI P.H., TAKHSHA M, JAMSHID K.A., HAGHSHENAS A. Assessment level of heavy metals $(\mathrm{Pb}$, $\mathrm{Cd}, \mathrm{Hg}$ ) in four fish species of persian gulf (Bushehr- Iran). International Journal of Advanced Technology \& Engineering Research 4, (2), 34, 2014.
14. AKPANYUNG E.O., EKANEMESANG U.M., AKPAKPAN E.I., ANADOZE N.O. Levels of heavy metals in fish obtained from two fishing sites in Akwa Ibom State, Nigeria. Afr. J. Environ Sci. Technol. 8, (7), 416, 2014.

15. CANLI M., ATLI G. The relationships between heavy metal $(\mathrm{Cd}, \mathrm{Cr}, \mathrm{Cu}, \mathrm{Fe}, \mathrm{Pb}, \mathrm{Zn})$ levels and the size of six Mediterranean fish species. Envirol. Pollut. 121, 129, 2003.

16. BAHNASAWY M., KHIDR A.A., DHEINA N. Assessment of heavy metal concentrations in water, plankton, and fih of Lake Manzala, Egyp. Turk. J. Zool. 35, (2), 271, 2011.

17. JELODAR H.T., BAEI M.S., NAJAFPOUR Sh., FAZLI H. The comparison of heavy metals concentrations in different organs of Liza aurata inhabiting in southern part of Caspian Sea. World Appl. Sci. J., 14, 96, 2011.

18. BASHIR F.H., OTHMAN M.S., MAZLAN A.G., RAHIM S.M., SIMON K.D. Heavy metal concentration in fishes from the coastal waters of Kapar and Mersing, Malaysia. Turk. J. Fish. Aquat. Sci. 13, 375, 2013.

19. AKAN J.C., MOHMOUD S., YIKALA B.S., OGUGBUAJA V.O. Bioaccumulation of some heavy metals in fish samples from river Benue in Vinikilang, Adamawa State, Nigeria. Am. J. Anal. Chem. 3, 727, 2012.

20. MESHRAM L.N., UDAWANT S.M., PAWAR S, MISHRA P.S. Bioaccumulation of heavy metals $(\mathrm{Zn}, \mathrm{Pb}, \mathrm{Cd}$, and $\mathrm{Ni}$ ) in tissues of Penaeus monodon (Fabricius, 1798) from India. Int. J. Adv. Res. 2, (3), 548, 2014.

21. POURANG N., DENNIS J.H., GHOURCHIAN H. Distribution of heavy metals in Penaeus semisulcatus from Persian Gulf and possible role of metallothionem in their redistribution during storage. Environ. Monit. Assess. 100, 71, 2005.

22. KRISHNA P.V., JYOTHIRMAYI V., RAO K.M. Human health risk assessment of heavy metal accumulation through fish consumption, from Machilipatnam Coast, Andhra Pradesh, India. Int. Res. J. Public Environ. Health. 1, (5), 121, 2014.

23. KÜLCÜ A.M., AYAS D., KÖŞKER A.R., YATKIN K. The Investigation of metal and mineral levels of some marine species from the Northeastern Mediterranean Sea. J. Mar. Biol. Oceanogr. 3, (2), 1, 2014.

24. RENIERI E.A., ALEGAKIS A. K., KIRIAKAKIS M., VINCETI M., OZCAGLI E., WILKS M.F., TSATSAKIS A.M. $\mathrm{Cd}, \mathrm{Pb}$ and $\mathrm{Hg}$ Biomonitoring in Fish of the Mediterranean Region and Risk Estimations on Fish Consumption. Toxics. 2, 417, 2014.

25. YILMAZ A.B. Levels of heavy metals ( $\mathrm{Fe}, \mathrm{Cu}, \mathrm{Ni}, \mathrm{Cr}, \mathrm{Pb}$, and $\mathrm{Zn}$ ) in tissue of Mugil cephalus and Trachurus mediterraneus from Iskenderun Bay, Turkey. Environ. Res. 92, 277, 2003.

26. YILMAZ F., ÖZDEMIR N., DEMIRAK A., TUNA A. L. Heavy metal levels in two fish species Leuciscus cephalus and Lepomis gibbosu. Food Chem. 100, 830, 2007.

27. KALAY M., AY Ö., CANLI M. Heavy metal concentrations in fish tissues from the Northeast Mediterranean Sea. Bull. Environ. Contam. Toxicol. 63, 673, 1999.

28. TURKMEN A., TURKMEN M., TEPE Y., AKYURT I. Heavy metals in three commercially valuable fish species from Iskenderun Bay, Northern East Mediterranean Sea, Turkey. Food Chem. 91, 167, 2005.

29. EL-MOSELHY Kh.M., OTHMAN A.I., EL-AZEM H. A. Bioaccumulation of heavy metals in some tissuesof fish in the Red Sea, Egypt. Egypt. J. Basic. Appl. Sci. 1, 97, 2014. 